\title{
Respon Return Pasar Modal Indonesia terhadap Kebijakan Moneter Domestik dan Asing
}

\author{
Aulia Yuliyanti Wulandari ${ }^{1 *}$, Noer Azam Achsani ${ }^{2}$, and Lukytawati Anggraeni ${ }^{2}$ \\ ${ }^{1}$ Mahasiswa Pascasarjana, Departemen Ilmu Ekonomi, Fakultas Ekonomi dan \\ Manajemen, Institut Pertanian Bogor, Indonesia \\ ${ }^{2}$ Staf Pengajar, Departemen Ilmu Ekonomi, Fakultas Ekonomi dan Manajemen, Institut \\ Pertanian Bogor, Indonesia \\ Korespondensi: aulia_proud@hotmail.com
}

[diterima: 7 Mei 2018 - revisi 20 Mei 2018 - diterbitkan daring: 31 Mei 2018]

\begin{abstract}
ABSTRAK
Memahami dampak guncangan eksternal pada return pasar saham dan volatilitas sangat penting bagi pelaku pasar karena volatilitas identik dengan risiko. Makalah ini memberikan bukti yang komprehensif tentang efek spillover dari perubahan kebijakan moneter dari dalam negeri dan luar negeri di pasar saham Indonesia dalam periode waktu dari 2 November 2012 hingga 15 Mei 2017. Model analisis simetris (IGARCH) dan asimetris (EGARCH dan APARCH) GARCH digunakan untuk mengevaluasi dampak dari kejutan dan mengantisipasi perubahan kebijakan moneter dari dalam dan luar negeri (dari negara-negara di luar ASEAN dan negara dengan perekonomi maju, dalam makalah ini adalah Amerika Serikat, Eropa, dan Inggris). Perubahan kejutan dari kebijakan moneter diproksikan oleh perubahan satu hari dalam 3 bulan interbank offered rate, sementara perubahan yang diantisipasi dari kebijakan moneter diproksikan oleh satu hari perubahan dalam target interest rate atau policy rate. Hasil dari analisis ini menunjukkan bahwa informasi berita terkait dengan kebijakan moneter dan return saham Indonesia adalah asimetris. Pasar saham Indonesia hanya dipengaruhi oleh kebijakan moneter asing.
\end{abstract}

ABSTRACT
Understanding the impact of external shocks on the stock market return and volatility is crucial for market participants as volatility is synonymous with risk. This paper provides comprehensive evidence on the spillover effects of the change of monetary policies from inside country and foreign origins on Indonesia stock market in the period of the time from November 2, 2012 to May 15, 2017. Used symmetric (IGARCH) and asymmetric (EGARCH and APARCH) GARCH model analysis to evaluate the impact of surprise and anticipated changes of monetary policies from inside country and foreign policies (from another ASEAN countries and leading economies, in this paper are United States, Europe, and United Kingdom). Surprise change of monetary policy is proxied by one day change in 3 months interbank offered rate, while anticipated change of monetary policy is proxied by one day change in target interest rate or policy rate. The result shows that information of the monetary policy news and Indonesia stock return is asymmetric. Indonesia stock market is only affected by foreign monetary policies.

Keywords: ASEAN stock market, GARCH, Monetary policy

JEL classification: C01, C50, E50 


\section{PENDAHULUAN}

Mishkin (1996) menguraikan dua pandangan dimana kebijakan moneter dapat memengaruhi harga saham, yaitu pandangan monetaris dan pandangan Keynesian. Pandangan monetaris mengemukakan bahwa kebijakan moneter ekspansif akan meningkatkan keseimbangan uang optimal dan karenanya akan meningkatkan permintaan untuk ekuitas (saham) dan menaikan harga ekuitas tersebut. Di lain sisi, Keynesian berpendapat bahwa penurunan suku bunga yang berasal dari kebijakan moneter ekspansif membuat obligasi kurang menarik dibandingkan ekuitas menyebabkan harga ekuitas naik. Berdasarkan pemaparan ini, pengumuman kebijakan moneter (target/kebijakan suku bunga) dapat memengaruhi performa pasar modal, yaitu pada kondisi indeks harga, return, maupun volatilitas saham.

Beberapa penelitian empiris membuktikan adanya pengaruh kebijakan moneter yang bersumber dari dalam maupun luar negeri terhadap suatu pasar modal. Penelitian yang membahas pengaruh kebijakan moneter domestik terhadap pasar modal telah dilakukan (Wang dan Mayes 2012; Vithessonthi dan Techarongrojwong 2013; Tsai 2014; serta Marfatia 2014). Sedangkan penelitian yang membahas pengaruh kebijakan moneter asing terhadap suatu pasar modal telah dilakukan Kim dan Nguyen (2009), Ravn (2013), Ricci (2014), Ruiz (2015) untuk kasus negara maju, sedangkan Vithessonthi dan Techarongrojwong (2012), Pennings et al. (2015), serta Tillmann (2016) meneliti negara berkembang.

Yang (2014) menjelaskan bahwa selama beberapa dekade terakhir, pasar saham di Association of Southeast Asian Nations (ASEAN), termasuk Indonesia, semakin matang terintegrasi ke dalam pasar modal dunia. Ini diperkuat dengan hasil penelitian Tamisari et al. (2016) serta Febrian dan Herwany (2009) yang membahas integrasi antar pasar modal ASEAN dan Karim et al. (2009) yang memaparkan integrasi pasar modal Indonesia dengan tiga negara rekan dagang utamanya. Indonesia merupakan salah satu negara yang memiliki pasar keuangan yang cukup berkembang terutama pasar saham. Indonesia Oxford Business Review (2018) mengungkapkan bahwa Bursa Efek Indonesia (BEI) terus tumbuh lebih cepat daripada mayoritas pasar di negara maju dan berkembang di seluruh dunia. Indeks Harga Saham Gabungan/ Jakarta Composite Index (JCI) mencatat pertumbuhan tertinggi kedua di Asia setelah Thailand, mengalahkan indeks utama seperti Kospi di Korea Selatan dan Nikkei Jepang. JCI tumbuh hingga 19,99\% pada tahun 2017 ketika indeks mencapai titik tertinggi sepanjang masa di 6.355,65 (Global Business Guide Indonesia 2017).

Berdasarkan penjelasan mengenai hubungan antara pasar modal dengan kebijakan moneter baik bersumber dari domestik dan asing, integrasi pasar modal Indonesia dengan negara lain, dan potensi pasar modal Indonesia, maka penting untuk meneliti lebih lanjut pengaruh kebijakan moneter domestik dan asing terhadap pasar modal Indonesia. Penelitian ini melanjutkan Putri et al. (2017) yang menganalisa dampak federal fund rate dan BI rate terhadap abnormal return sembilan 
sektor pasar modal Indonesia. Pembaharuan yang dilakukan pada penelitian ini terletak pada perbandingan metode GARCH (Generalized Autoregressive Conditional Heteroskedasticity) yang digunakan untuk mengevaluasi dampak kebijakan moneter yang diteliti terhadap return JCI dan komponen kebijakan moneter asing yang lebih banyak, yaitu pengaruh kebijakan moneter dari beberapa negara ASEAN lainnya (Singapura, Malaysia, dan Thailand) dan tiga leading economy yang kebijakan moneternya berpengaruh di dunia (Amerika Serikat (Abou-Zaid 2013; Kim dan Nguyen 2009), Eropa (Kim dan Nguyen 2009), dan Inggris (Wang dan Mayes 2012)). Indikator kebijakan moneter yang digunakan pada penelitian ini mengacu pada Bernanke dan Kuttner (2005), Kim dan Nguyen (2009), dan Abou Zaid (2013) yang mengategorikan kebijakan moneter sebagai perubahan suku bunga yang expected (diantisipasi) dan unexpected (surprise).

Penelitian ini bertujuan untuk menganalisis respon return pasar modal Indonesia (return JCI) dengan adanya perubahan pada kebijakan moneter domestik (Bank Indonesia) dan asing yang berpengaruh di dunia yang bersumber dari bank sentral Amerika Serikat, Eropa, dan Inggris, serta negara ASEAN lainnya (Singapura, Malaysia, dan Thailand).

\section{TINJAUAN PUSTAKA}

\section{Random Walk Hyphotesis dan Efisiensi Pasar}

Teori random walk menunjukkan bahwa perubahan harga saham memiliki distribusi yang sama dan independen satu sama lain, sehingga gerakan masa lalu atau tren harga saham atau pasar tidak dapat digunakan untuk memprediksi pergerakan masa depan. Hipotesis pasar yang efisien/ Efficient Market Hypothesis (EMH) mengatakan bahwa harga saham sepenuhnya mencerminkan semua informasi dan harapan yang tersedia, sehingga harga saat ini adalah pendekatan terbaik dari nilai intrinsik perusahaan (Fama 1969).

Dornbusch et al. (2008) menuliskan pola acak (random walk) dari harga saham kedalam suatu persamaan, yaitu:

$$
P_{t+1}=a+P_{t}+\dot{\mathrm{d}}
$$

Persamaan (1) merupakan garis $45^{\circ}$ yang memotong sumbu vertical sedikit diatas titik $(0,0)$ dari plot harga indeks harga saham yang datanya tersebar rapat di sekitar garis tersebut, dimana $a$ bernilai amat kecil dan merepresentasikan pengembalian saham, sedangkan dं merepresentasikan perubahan harga saham yang tak terduga. Persamaan (1) menyatakan bahwa dengan menyisihkan $a$ maka perubahan harga saham, $\ddot{A} P=a+$ ḋ, menjadi tak terduga. Selain itu, persamaan (1) menyatakan bahwa dengan mengikuti gejolak, harga saham tidak memiliki tendensi, kembali ke tingkat normal. Melainkan, perubahan harga saham bersifat independen sepanjang waktu. 
Pola acak pada persamaan (1) menandakan efisiensi pasar.

\section{Hubungan Pasar Modal dengan Kebijakan Moneter}

\section{Teori Pertumbuhan Gordon}

Model pertumbuhan Gordon (persamaan 2) menjelaskan mengenai bagaimana kebijakan moneter memengaruhi harga saham (Mishkin 2008).

$$
P_{0}=\frac{D_{0} \times(1+g)}{\left(k_{e}-g\right)}
$$

dimana:

$\begin{array}{ll}P_{0} & \text { :harga saham } \\ D_{0} & \text { :dividen yang paling terakhir } \\ & \text { dibayarkan } \\ g & \text { :perkiraan tingkat } \\ & \text { pertumbuhan dividen yang } \\ & \text { konstan } \\ k_{e} \quad & \text { :tingkat imbal hasil atas } \\ & \text { investasi dalam ekuitas yang } \\ & \text { disyaratkan }\end{array}$

Kebijakan moneter dapat memengaruhi harga saham dengan dua cara. Pertama, ketika bank sentral menurunkan suku bunga, imbal hasil atas obligasi (asset alternatif dari saham) turun, dan investor bersedia menerima tingkat imbal hasil atas investasi yang disyaratkan $\left(k_{e}\right)$ yang lebih rendah dari ekuitas. Penurunan $k_{e}$ akan menurunkan penyebut dalam model pertumbuhan Gordon (persamaan 2), mendorong nilai $P_{0}$ yang lebih tinggi, dan menaikkan harga saham. Lebih lanjut, penurunan suku bunga akan mendorong perekonomian, sehingga laju pertumbuhan dividen akan lebih tinggi. Kenaikan $g$ ini menyebabkan penyebut dalam persamaan 2 turun, dan semakin mendorong $P_{0}$ lebih tinggi dan meningkatkan harga saham.
Dampak kebijkan moneter terhadap harga saham merupakan cara bagaimana kebijakan moneter memengaruhi perekonomian.

Bernanke dan Kuttner (2003) fokus meneliti pada perubahan dalam kebijakan moneter yang tidak terduga oleh pelaku pasar karena perubahan yang diantisipasi dalam kebijakan dinilai sudah didiskon oleh investor pasar saham dan, karenanya, tidak mungkin mempengaruhi harga ekuitas pada saat diumumkan. Mereka menemukan bahwa perubahan tak terduga dalam kebijakan moneter mempengaruhi harga saham tidak begitu banyak dengan mempengaruhi dividen yang diharapkan atau tingkat bunga riil bebas risiko, tetapi dengan mempengaruhi keberisikoan saham yang dirasakan. Pengetatan kebijakan moneter, misalnya, mengarahkan investor untuk melihat saham sebagai investasi berisiko dan dengan demikian menuntut pengembalian yang lebih tinggi untuk menahan saham. Untuk jalur tertentu dari dividen yang diharapkan, laba yang diharapkan lebih tinggi dapat dicapai hanya dengan jatuhnya harga saham saat ini. Bernanke (2003) menyatakan dalam pidatonya bahwa kebijakan moneter yang longgar meningkatkan harga saham, sementara kebijakan yang lebih ketat menurunkan harga saham.

Nguyen et al. (2016) menunjukkan bahwa kebijakan moneter termasuk suku bunga, nilai tukar, dan rasio cadangan wajib memiliki dampak negatif terhadap harga saham dalam jangka panjang. Suku bunga memiliki efek negatif pada harga saham. Ini menunjukkan bahwa pengetatan moneter (meningkat suku bunga) akan membuat pasar saham menurun. 
Dalam kasus inflasi tinggi, bank-bank negara telah memperketat kebijakan moneter dengan menaikkan suku bunga, yang dalam jangka pendek tidak akan mempengaruhi pasar saham, tetapi dalam jangka panjang. Hal tersebut memiliki pengaruh negatif terhadap bisnis, terutama perusahaan yang menggunakan sejumlah besar pinjaman bank untuk operasi bisnis mereka. Hasil penelitian ini selaras dengan penelitian sebelumnya (Ali 2014; Dufour dan Tessier 2006; Fischbacher 2012; Zare et al. 2013; Gali dan Gambetti 2013).

\section{Integrasi Ekonomi: Persekutuan Pabean}

Salvatore (1996) menjelaskan bahwa pada tingkatan tertinggi dari integrasi ekonomi, yakni uni ekonomi (economic union), harmonisasi dilakukan lebih jauh, bahkan dengan menyeragamkan kebijakan-kebijakan moneter dan fiskal dari masingmasing negara anggota. Ini merupakan tipe kerja sama ekonomi yang paling tinggi. Contohnya adalah Uni Eropa yang merupakan perombakan dari Benelux ( uni ekonomi dari Belanda, Belgia, dan Luxemburg). Sedangkan contoh uni ekonomi yang benar-benar menyeluruh secara ekonomi dan moneter adalah Amerika Serikat. Masing-masing negara bagian memperlakukan negara bagian lain tidak ubahnya dengan dirinya sendiri.

\section{Penelitian Terdahulu}

Rangkuman mengenai hubungan variabel dan metode yang digunakan dalam beberapa literatur terdahulu tersaji dalam Tabel 1.

Tabel 1 Rangkuman Penelitian Terdahulu

\begin{tabular}{|c|c|c|c|}
\hline No & $\begin{array}{c}\text { Judul Penelitian, } \\
\text { Nama Penulis,Tahun } \\
\text { Penelitian }\end{array}$ & Metode Analisis & $\begin{array}{c}\text { Variabel dan Tanda } \\
\text { Koefisien Hasil } \\
\text { Estimasi }\end{array}$ \\
\hline 1 & $\begin{array}{l}\text { The Spillover Effects of } \\
\text { Target Interest Rate } \\
\text { News from The U.S } \\
\text { Fed and The European } \\
\text { Central Bank On the } \\
\text { Asia-Pasific Stock } \\
\text { Markets Oleh: Suk- } \\
\text { Joong Kim dan Qo } \\
\text { Quoc Tho Nguyen } \\
\text { (2009) }\end{array}$ & EGARCH & $\begin{array}{l}\text { Perubahan yang tidak } \\
\text { diperkirakan dari suku } \\
\text { bunga target Fed dan } \\
\text { ECB memberikan } \\
\text { dampak (-) signifikan } \\
\text { terhadap return di } \\
\text { pasar modal Asia } \\
\text { Pasifik. Ada respon } \\
\text { signifikan } \\
\text { volatilitas pasar modal } \\
\text { terhadap }\end{array}$ \\
\hline 2 & $\begin{array}{l}\text { Internatinal Stock } \\
\text { Markets Response to } \\
\text { the Federal Reserve } \\
\text { Policy Actions: The } \\
\text { Case of Emerging }\end{array}$ & GARCH & $\begin{array}{l}\text { bunga. } \\
\text { Berdasarkan } \\
\text { mayoritas hasil: } \\
\text { Federal Fund Future } \\
\text { signifikan negatif, } \\
M E N A_{t-1} \text { berdampak }\end{array}$ \\
\hline
\end{tabular}


MENA Markets Oleh: Ahmed S. Abou-Zaid (2013)

Comparing U.S. and European Market

3 Volatility Responses to Interest rate Policy Announcements Oleh: Kevin Krieger, Nathan Mauck, dan Joseph Vazquez (2015)

Monetary Policy and Stock Prices - CrossCountry Evidence

4 from Cointegrated VAR Models Oleh: Ansgar Belke dan Joscha Beckmann (2014)

Response of Spanish stock market to ECB

5 monetary policy during financial crisis Oleh: Javier Ruiz (2015)

Do monetary policy announcements affect stock prices in emerging market countries?The case of 6 Thailand Oleh: Chaiporn Vithessonthi dan Yaowaluk Techarongrojwong (2013)

Monetary policy

$7 \quad$ announcements and stock reactions: An international signifikan positif, $S \& P_{t-1} \quad$ berdampak negatif tidak signifikan terhadap return MENA.

VDAX menurun pada hari-hari pertemuan FOMC. VDAX menurun pada harihari pertemuan ECB. VAR VIX menurun pada hari pertemuan FOMC, tetapi VIX tidak berhubungan dengan pengumuman ECB.

Dampak jangka panjang dari suku bunga jangka pendek pada harga saham hanya dapat diamati pada 3 dari 8 ekonomi.

Kejutan kebijakan moneter dari ECB terbukti memiliki SVAR dampak jangka panjang terhadap pasar modal Spanyol.

Ada dampak signifikan dari perubahan yang diharapkan dalam Event Study tingkat kebijakan suku Approach bunga (+) dan international trade terhadap abnormal return

Riset menemukan bahwa Eropa dan Inggris menunjukkan efek krisis keuangan 
comparison Oleh:

Shen Wang dan David

G. Mayes (2012)

Impacts of Monetary

Policy and

Information Shock on

Stock Market: Case

8

Study in Vietnam

Oleh: Trung Thanh

Nguyen, Thi Linh Do, dan Van Duy Nguyen

(2016) $\begin{array}{lrr}\text { tetapi perilaku } & \text { di } \\ \text { Selandia } & \text { Baru } & \text { dan } \\ \text { Australia } & & \text { tidak } \\ \text { berubah. } & & \end{array}$

Hasil menunjukkan

bahwa kebijakan

moneter termasuk

suku bunga, nilai

tukar, dan rasio

cadangan wajib

memiliki dampak

GJR negatif terhadap harga

GARCH, ARDL saham dalam jangka

panjang. Selain itu,

guncangan pasar yang

buruk atau baik

menyebabkan

perubahan harga

saham pada tingkat

stabil.
Penelitian ini melanjutkan topik studi yang telah dilakukan oleh Belke dan Beckmann (2014). Perbedaan penelitian ini dengan penelitian sebelumnya adalah dengan membandingan pengaruh kebijakan moneter dalam negeri dari Bank Indonesia dan kebijakan moneter luar negeri (AS, EU, Inggris, dan negara ASEAN lainnya) terhadap pasar modal Indonesia dengan fokus pada return pasar modal Indonesia (RJCI). Penelitian ini mengacu pada model riset milik Abou-Zaid (2013), Wang dan Mayes (2012), Kim dan Nguyen (2009), dan Nguyen et al (2016). Studi ini mengadopsi metode univariat GARCH (Kim dan Nguyen, 2009). Inovasi yang dilakukan oleh peneliti adalah memodelkan RJCI kedalam kelompok dua pemodelan besar, yaitu model univariat GARCH simetris (IGARCH) dan asimetris (APARCH dan EGARCH) yang akan dievaluasi pada satu model terbaik .

\section{Kerangka Pemikiran Operasional}

Keterkaitan antara perumusan masalah, tujuan penelitian dan metode penelitian dapat dilihat dari kerangka pemikiran operasional yang tersaji pada Gambar 1. Berdasarkan teori dan penelitian-penelitian terdahulu, maka permasalahan pada penelitian ini akan dijawab dengan menggunakan pendekatan model GARCH. Secara sistematis kerangka pemikiran operasional dapat dijelaskan oleh Gambar 1 dibawah ini. 
Hubungan kebijakan moneter dengan indeks harga saham, return, dan volatilitas di pasar modal

Pengaruh kebijakan moneter dalam negeri (Bank Indonesia) dan luar negeri (bank sentral Amerika Serikat, Eropa, Inggris, dan negara ASEAN lainnya:

Singapura, Malaysia, dan Thailand) pada pasar modal Indonesia

Permasalahan:

Bagaimana respon return pasar modal Indonesia (JCI)?

$\downarrow$

Menganalisis respon return pasar modal Indonesia (JCI)

$\downarrow$

Metode Analisis deskriptif dan univariat GARCH (Mean Equation)

Imnlikasi dan Rekomendasi Kebiiakan

Gambar 1 Kerangka Penelitian Operasional

\section{METODE PENELITIAN}

\section{Jenis dan Sumber Data}

Jenis data yang digunakan dalam penelitian ini adalah data sekunder berupa data deret waktu harian dengan periode data dari 2 November 2012 hingga 15 Mei 2017. Data yang digunakan adalah daily closing prices untuk mewakili indeks harga saham empat negara ASEAN (Singapura/ The Straits Times Index (STI), Malaysia/ Kuala Lumpur Composite Index (KLCI), Indonesia/ Jakarta Composite Index (JCI), dan Thailand/ Stock Exchange of Thailand Index (SET)) serta tiga indeks utama dunia dari Amerika Serikat/ Dow Jones Index (DJI), Eropa/ Deutsche Boerse AG German Stock Index (DAX), dan Inggris/ The
Financial Times Stock Exchange 100 Index (FTSE).

Data indikator kebijakan moneter yang dapat diantisipasi menggunakan perubahan satu hari pada suku bunga kebijakan. Sedangkan perubahan kebijakan moneter yang tidak diantisipasi diproksikan dengan perubahan satu hari 3 months interbank offered rate. Data indeks harga saham diperoleh dari Bloomberg Database dan Yahoo Finance, sedangkan data indikator kebijakan moneter diperoleh dari website masing-masing bank sentral, Bloomberg Database, dan Router Database. Indeks harga saham kemudian ditransformasikan kedalam bentuk return dengan logaritma natural. Tabel 2 berikut merinci variabel yang digunakan dalam penelitian. 
Tabel 2 Daftar Variabel

\begin{tabular}{lcc}
\hline \multicolumn{1}{c}{ Return } & Policy Rate & 3 months Interbank Offered Rate \\
\hline RJCI Indonesia) & PRBI & JIBOR3MO \\
RSTI (Singapura) & PRMAS & SIBOR3MO \\
RKLCI (Malaysia) & PRBNM & KLIBOR3MO \\
RSET (Thailand) & PRBOT & BKIBOR3MO \\
RDJIA (Amerika Serikat) & PRFED & EFFR \\
RDAX (Eropa) & PRECB & EURIBOR3MO \\
RFTSE (Inggris) & PRBOE & LIBORGBP3MO \\
\hline
\end{tabular}

\section{Metode Analisis dan Pengolahan Data}

Penelitian ini menggunakan metode analisis yang bersifat deskriptif, dan kuantitatif. Alat analisis yang digunakan untuk menjawab permasalahan dalam penelitian ini adalah evaluasi model dengan metode evaluasi univariat simetris dan asimetris generalized autoregressive conditional heteroskedasticity (GARCH). Sebelum mencari model GARCH terbaik, dilakukan analisis kuantitatif sederhana berupa analisis korelasi parsial antara RJCI dengan policy rate dan 3 months interbank offered rate yang digunakan sebagai variabel independen dalam pemodelan GARCH. Selanjutnya setelah didapatkan model GARCH terbaik,

Persamaan (3) untuk menjawab respon return pasar modal ASEAN (mean equation):

$$
\begin{aligned}
r_{J C I t}= & \mu_{i}+\omega_{1} r_{J C I t-1}+\cdots+\omega_{p} r_{J C I t-p}+ \\
& \delta_{i} I_{i, t}+\vartheta_{i} J_{i t}+\partial_{i} F S I_{i t-1} \emptyset_{i} F F_{i t-1}+ \\
& \tau_{i} F C_{i t}+\theta_{1} \varepsilon_{t-1}+\theta_{q} \varepsilon_{t-q}
\end{aligned}
$$

dimana:

$r_{J C I t}=$ return saham pasar modal Indonesia (RJCI) pada waktu $\mathrm{t}$

$\mu_{i} \quad=$ konstanta untuk menentukan besar pengaruh absolut suatu variabel akan digunakan analisis koefisien baku. Perangkat lunak yang digunakan untuk proses pengolahan adalah Microsoft Excel 2007 dan Eviews 6.

\section{Model Penelitian}

Model dan variabel yang digunakan pada penelitian ini diadopsi dari penelitian yang telah dilakukan oleh Bernanke dan Kuttner (2005), Kim dan Nguyen (2009), Wang dan Mayes (2012), Abou-Zaid (2013), dan Nguyen et al (2016). Model GARCH (Kim dan Nguyen 2009 dan Abou-Zaid 2013) yang digunakan, yaitu mean equation. Berikut merupakan mean equation model GARCH yang digunakan:

$\omega_{p} \quad=$ koefisien besar pengaruh autoregresif pada lag-ke $\mathrm{p}$ $\left(\begin{array}{cc}\omega_{p} & >0 \text { artinya } r_{J C I t-p}\end{array}\right.$ berpengaruh positif terhadap $r_{J C I t}$ vice versa)

$r_{J C I t-p}=$ komponen autoregresif hingga lag-p return JCI

$\begin{array}{rlr}\delta_{i} & =\text { koefisien } & \text { pengaruh } \\ \text { perubahan } & \text { kebijakan } \\ \text { moneter } & \text { yang dapat } \\ \text { diantisipasi } & \text { ASEAN } \\ & \text { (Indonesia/PRBI, } \\ & \text { Singapura/PRMAS, }\end{array}$


Malaysia/PRBNM,

Thailand/PRBOT) terhadap return pasar modal RJCI yang diestimasi $\left(\delta_{i}<0\right)$

$\vartheta_{i}=$ koefisien pengaruh kebijakan moneter yang dapat diantisipasi Amerika Serikat (PRFED), Eropa (PRECB), dan Inggris (PRBOE) terhadap return pasar modal RJCI yang diestimasi $\left(\vartheta_{i}<0\right)$

$I_{i t} \quad=$ perubahan satu hari suku bunga kebijakan moneter ASEAN yang dapat diantisipasi/terjadwal

(Indonesia/PRBI,

Singapura/PRMAS,

Malaysia/PRBNM,

Thailand/PRBOT)

$J_{i t} \quad=$ perubahan satu hari suku bunga kebijakan moneter Amerika Serikat (PRFED), Eropa (PRECB), dan Inggris (PRBOE) yang dapat diantisipasi/terjadwal

$\partial_{\mathrm{i}}=$ koefisien (indikator integrasi) Foreign Stock Index Return /FSI dari negara ASEAN lainnya dan leading world index return $\left(\partial_{i}>0\right)$

$\emptyset_{i} \quad=$ koefisien pengaruh kebijakan moneter tidak diantisipasi dari Amerika Serikat, Eropa, dan Inggris $\left(\emptyset_{\mathrm{i}}<0\right)$

$F F_{i t-1}=$ perubahan satu hari 3 months interbank offered rate dari Amerika Serikat (EFFR), Eropa (EURIBOR3MO), dan Inggris (LIBORGBP3MO) pada waktu t-1. Periode t-1 digunakan karena perbedaan zona waktu.

$\tau_{i} \quad=$ koefisien pengaruh kebijakan moneter tidak diantisipasi dari ASEAN

$\left(\tau_{i}<0\right)$

$F C_{i t}=$ perubahan satu hari 3

months interbank offered

rate dari ASEAN

(Indonesia/JIBOR3MO,

Singapura/SIBOR3MO,

Malaysia/KLIBOR3MO,

Thailand/BKIBOR3MO)

pada waktu $\mathrm{t}$

$F S I_{i t, i t-1}=$ Foreign Stock Index Return

pada $\mathrm{t}$ untuk ASEAN lain

(Singapura (RSTI), Malaysia

(RKLCI) dan Thailand

(RSET) dan t-1 (RDJIA,

RDAX, RFTSE)

$\theta_{q} \quad=$ koefisien besar pengaruh moving average pada lag-ke

$\mathrm{q}$

$\varepsilon_{t-q} \quad=$ komponen moving average

hingga lag-q

Berikut merupakan spesifikasi volatility equation yang digunakan untuk memodelkan guna mendapatkan GARCH terbaik:

Model simetris GARCH

1. IGARCH (Integrated GARCH)

Model IGARCH diusulkan oleh

Engle dan Bollerslev (1986). Model IGARCH memiliki restriksi yakni total nilai dugaan parameternya sama dengan satu. Model IGARCH diekspresikan pada Persamaan 4 (Awartani dan Corradi 2005) berikut: $\sigma_{i t}^{2}=c_{i}+\sum_{i=1}^{p} \beta_{i}\left(\sigma_{i t-1}^{2}\right)+$ dimana $1-\sum_{i=1}^{p} \beta_{i}-\sum_{i=1}^{q} \alpha_{i}=0$

Model asimetris GARCH yang digunakan antara lain:

2. APARCH (Asymmetric Power ARCH)

APARCH dimodelkan oleh Ding et al. (1993), model tersebut diekspresikan dalam Persamaan 5 (Awartani dan Corradi 2005). 


$$
\begin{aligned}
\left(\sigma_{i t}\right)^{\delta}= & c_{i}+\sum_{i=1}^{p}\left(\sigma_{t-i}\right)^{\delta}+ \\
& \sum_{i=1}^{q}\left(\alpha_{i}\left|\varepsilon_{i, t-i}\right|-\gamma_{i} \varepsilon_{i, t-i}\right)^{\delta}
\end{aligned}
$$

dimana $0<\delta$ and $-1<\gamma<1$.

\section{EGARCH \\ GARCH)}

(Exponential

Nelson (1991) mengenalkan satu dari beberapa model asimetris GARCH, yakni EGARCH dengan menyusun exponential GARCH. Model EGARCH dapat diekspresikan pada Persamaan 6 (Awartani dan Corradi 2005) sebagai berikut:

$$
\begin{aligned}
\ln \left(\sigma_{i t}^{2}\right)= & c_{i}+ \\
& \sum_{i=1}^{q}\left\{\alpha_{i} \frac{\left|\varepsilon_{i, t-1}\right|}{\sigma_{i . t-1}}+\gamma_{i} \frac{\varepsilon_{i, t-1}}{\sigma_{i . t-1}}+\right. \\
& \sum_{i=1}^{p} \beta_{i} \ln \left(\sigma_{i t-1}^{2}\right)
\end{aligned}
$$

\section{Koefisien Baku}

Cara untuk mengkaji relatif pentingnya masing-masing peubah bebas terhadap peubah terikat/ variabel dependen dapat menggunakan koefisien baku (standardized coefficients). Berikut merupakan formula koefisien baku yang digunakan dalam penelitian ini:

$$
A^{*}=\left|\frac{A}{[\text { standar error }]}\right|
$$

dimana:

$$
\begin{aligned}
& \mathrm{A} * \quad \text { koefisien baku suatu } \\
& \text { variabel } \mathrm{A}
\end{aligned}
$$

$\mathrm{A}=$ koefisien baku indikator/ variabel independen A hasil estimasi GARCH.

\section{Data Generating Process}

Firdaus (2011) menghitung return harian dari data indeks harga dimana:

$c_{i} \quad=$ konstanta

$\alpha_{i} \quad=$ magnitude effect (besarnya pengaruh volatilitas pada periode $\mathrm{t}-\mathrm{p}$ terhadap ragam saat ini), $\quad \alpha_{i}>0$ volatilitas pada periode t-p berdampak positif pada ragam saat ini

$\sigma_{i t}^{2} \quad=$ conditional variance

$\beta_{i}=$ persistensi volatilitas pasar $\left(\beta_{i}>0\right)$

$\gamma_{i}=$ bernilai negatif dan signifikan menandakan guncangan berita negatif pada pasar modal menimbulkan volatilitas yang lebih besar daripada berita positi (leverage effect $\gamma_{i} \neq 0$; asimetrik $\gamma_{i}<0$ )

saham dengan menggunakan daily closing prices. Return pasar $\left(r_{i t}\right)$ yang dapat dihitung dengan:

$$
r_{i t}=\ln \frac{P_{t}}{P_{t-1}}
$$

keterangan:

$r_{i t}=$ Return pasar modal negara $\mathrm{i}$ pada periode $t$

$P_{t} \quad=$ Indeks harga saham gabungan pada periode $\mathrm{t}$

$P_{t-1}=$ Indeks harga saham gabungan pada periode $t-1$.

Tahapan pengolahan data kuantitatif:

1. Menguji stasioneritas return indeks saham gabungan, deret harian perubahan suku bunga acuan, dan deret harian perubahan interbank overnight rate yang digunakan dalam penelitian dengan Augmented Dickey-Fuller (ADF) test. 
2. Estimasi dan mencari model ARMA (p,q) terbaik. Metode Box-Jenkins (ARMA) Tujuan pemodelan ARMA (Autoregressive Moving Average) adalah untuk menentukan hubungan statistik yang baik antar variabel yang diramal dengan nilai historis variabel tersebut sehingga peramalan dapat dilakukan dengan model tersebut. Model ARMA dibagi dalam tiga unsur, yaitu: model autoregresif (AR) dan moving average (MA). Bentuk umumnya ARMA(p,q). $\mathrm{p}$ menyatakan ordo AR dan $\mathrm{q}$ menyatakan ordo moving average. ARMA digunakan untuk suatu variabel (univariat) deret waktu.

3. Melakukan preliminary tests (Jarque-Bera, LM test, dan ARCH test) untuk menguji apakah model GARCH dapat digunakan. Setelah mendapatkan model ARMA terbaik, selanjutnya dilakukan identifikasi adanya heteroskedastisitas (efek ARCH) pada model dan data yang digunakan sehingga metode GARCH dapat digunakan. Cara menguji efek ARCH: Uji ARCH dengan $\mathrm{ARCH}$ test. Uji ARCH didasarkan pada hipotesis nol tidak terdapat ARCH error. Apabila hasil pengujian menunjukan penerimaan terhadap hipotesis nol, maka data tidak mengandung $\mathrm{ARCH}$ error atau data bersifat homoskedastisitas dan tidak perlu dimodelkan model GARCH dan turunannya. Uji
Jarque-Bera digunakan untuk melihat normalitas dari hasil estimasi ARIMA, sedangkan uji LM digunakan untuk melihat apakah model ARIMA sudah terbebas dari autokorelasi.

\section{Estimasi Model}

Pada tahap ini dilakukan estimasi terhadap nilai-nilai parameter model untuk menentukan model ARCHGARCH terbaik. Pendugaan parameter bertujuan untuk mencari koefisien model. Penentuan dugaan parameter ARCH-GARCH dilakukan dengan menggunakan metode maximum likelihood secara iterative dengan Algoritma Marquardt. Model terbaik dipilih dengan memperhatikan signifikansi model dari probabilitas statistik uji $\mathrm{F}$, signifikansi koefisien AR atau MA yang digunakan, adj Rsquared yang paling besar, signifikansi koefisien variabel, serta kriteria AIC dan SIC terkecil. Akaike Information Criterion (AIC) dan Schwartz Criterion (SC) merupakan dua standar informasi yang menyediakan ukuran informasi yang dapat menyeimbangkan antara ukuran kebaikan model dan spesifikasi model.

\section{Evaluasi Model}

Uji eksistensi efek ARCH (ARCH-LM) yang telah dijelaskan pada tahap-tahap sebelumnya. Uji ini dimaksudkan untuk memastikan masalah heteroskedastisitas telah terselesaikan dengan pemodelan GARCH. 


\section{Pergerakan Assets Return}

Analisis deskriptif data (Tabel 3) memberikan informasi bahwa ratarata return terbesar ditemukan pada pasar modal Eropa yang diwakili oleh indeks saham gabungan dari Jerman (RDAX) yaitu dengan return harian sebesar $0,000478 \%$, sedangkan ratarata return terkecil ditemukan pada pasar modal di Malaysia (RKLCI) yaitu $0,0000489 \%$ per harinya. Indonesia (RJCI) memiliki return saham tertinggi di ASEAN yaitu sebesar $0,000228 \%$ per harinya. Ratarata return terbesar yang dimiliki Indonesia disebabkan oleh adanya pertumbuhan pasar modal yang positif untuk Indonesia terutama setelah Bursa Efek Indonesia (BEI) terbentuk. Ini mengindikasikan bahwa pasar modal Indonesia lebih diminati oleh investor dibandingkan tiga negara ASEAN lainnya, sehingga pertumbuhan capital gain lebih cepat dan menghasilkan return pasar yang besar.

Standar deviasi terbesar ditemukan pada return Jerman (RDAX) yang mewakili Eropa dan yang terkecil pada return Malaysia. Sedangkan di ASEAN, pasar modal dengan volatilitas tertinggi adalah Indonesia yang ditandai dengan nilai standar deviasi RJCI yang bernilai paling tinggi dibandingkan dengan tiga negara ASEAN lainnya. Hasil ini selaras dengan hasil return tinggi dimana menandakan bahwa pada pasar modal dengan return pasar yang lebih tinggi lebih volatil atau bergejolak maupun berisiko dari pada pasar dengan return lebih rendah.

Korelasi terbesar ditemukan antara return DAX dengan return FTSE dengan nilai korelasi 0.808021 yang mengindikasikan adanya hubungan integrasi kuat antar pasar modal Jerman dan Inggris yang masih dalam satu kawasan Uni Eropa. Sedangkan di kawasan ASEAN, korelasi terbesar ditemukan antara return Singapura (STI) dan return Malaysia (KLCI). Hasil ini mengindikasikan bahwa taraf integrasi pasar modal di ASEAN paling tinggi antara Singapura dan Malaysia. Meskipun korelasi antar pasar modal negara-negara ASEAN terlihat lemah, yaitu kurang dari 0,8 nilai korelasinya, pasar modal ASEAN tetap terbukti saling berkorelasi sehingga dapat dikatakan bahwa terdapat integrasi antar pasar modal ASEAN.

Tabel 3 juga menyajikan informasi mengenai kecondongan dan distribusi return saham. Hasilnya menunjukkan bahwa return saham dari semua pasar modal yang dianalisis dalam penelitian ini mempunyai nilai kurtosis lebih dari 3, hal ini mengindikasikan bahwa distribusi dari return memiliki bentuk leptokurtic (Gokbulut dan Pekkaya 2014). Leptokurtic merupakan bentuk bagian tengah distribusi data yang mempunyai puncak lebih runcing. Nilai skewness menunjukkan kecondongan data, jika nilai skewness bernilai positif, artinya deret cenderung memiliki kecondongan ke kanan (long right tail), sebaliknya jika nilai skewness bernilai negatif, artinya deret cenderung memiliki kecenderungan ke kiri (long left tail).

Tabel 3 memperlihatkan bahwa skewness semua return saham bernilai negative yang berarti return saham cenderung memiliki kecondongan ke kiri (long left tail). Hal ini menggambarkan adanya ketidaksimetrisan dari distribusi normal. Ini diperkuat dengan bukti bahwa seluruh data return terbukti tidak menyebar normal dengan nilai 
probabilitas statistik Jarque-Bera yang signifikan menolak hipotesis nol yang berarti data tidak menyebar normal (nilai normality p-value kurang dari 5\%).

Tabel 3 Analisis Statistik Deskriptif untuk Asset Returns

\begin{tabular}{|c|c|c|c|c|c|c|c|}
\hline \multicolumn{8}{|c|}{ Panel A: Summary statistics } \\
\hline & RSTI & RKLCI & RJCI & RSET & RDJIA & RDAX & RFTSE \\
\hline Mean (\%) & 0,000064 & 0,000049 & 0,000228 & 0,000147 & 0,000395 & 0,000478 & 0,000213 \\
\hline Std. Dev. (\%) & 0,006968 & 0,005495 & 0,009766 & 0,009180 & 0,007487 & 0,011475 & 0,008765 \\
\hline Skewness & $-0,296593$ & $-0,154314$ & $-0,412878$ & $-0,407866$ & $-0,303667$ & $-0,383047$ & $-0,180606$ \\
\hline Kurtosis & 5,819493 & 6,435231 & 6,865094 & 7,512259 & 5,384542 & 5,399180 & 5,602521 \\
\hline Jarque-Bera & 408,8444 & 585,8809 & 769,3256 & 1035,526 & 298,2035 & 312,3909 & 340,0017 \\
\hline \multirow{3}{*}{$\begin{array}{l}\text { Normality } \\
\text { (p-value) }\end{array}$} & 0,000000 & 0,000000 & 0,000000 & 0,000000 & 0,000000 & 0,000000 & 0,000000 \\
\hline & \multicolumn{7}{|c|}{ Panel B: Pairwise Correlations } \\
\hline & RSTI & RKLCI & RJCI & RSET & RDJIA & RDAX & RFTSE \\
\hline RSTI & 1 & 0,478499 & 0,4562253 & 0,4186549 & 0,3550852 & 0,2105267 & 0,2475588 \\
\hline RKLCI & 0,478499 & 1 & 0,4725072 & 0,3500155 & 0,3347731 & 0,2280059 & 0,2759352 \\
\hline RJCI & 0,4562253 & 0,4725072 & 1 & 0,4229194 & 0,2911336 & 0,1698905 & 0,1932615 \\
\hline RSET & 0,4186549 & 0,3500155 & 0,4229194 & 1 & 0,1959328 & 0,0659045 & 0,0870992 \\
\hline RDJIA & 0,3550852 & 0,3347731 & 0,2911336 & 0,1959328 & 1 & 0,5518231 & 0,5726004 \\
\hline RDAX & 0,2105267 & 0,2280059 & 0,1698905 & 0,0659045 & 0,5518231 & 1 & 0,808021 \\
\hline RFTSE & 0,2475588 & 0,2759352 & 0,1932615 & 0,0870992 & 0,5726004 & 0,808021 & 1 \\
\hline
\end{tabular}

\section{Analisis Korelasi Parsial RJI dan Indikator Kebijakan Moneter}

Tabel 4 menunjukan analisis korelasi sederhana hubungan kebijakan moneter dengan return JCI (RJCI). Hipotesis awal yang dibangun adalah bahwa kebijakan moneter berhubungan negatif dengan return saham. Ini didasari oleh model pertumbuhan Gordon yang menjelaskan bagaimana kebijakan moneter berhubungan negatif dengan harga saham (Mishkin 2008). menunjukkan bahwa kebijakan moneter termasuk suku bunga, nilai tukar, dan rasio cadangan wajib memiliki dampak negatif terhadap harga saham dalam jangka panjang. Hasil penelitian ini selaras dengan penelitian sebelumnya (Zare et al. 2013; Gali dan Gambetti 2013; Putri et al 2017). Karena return saham disini adalah capital gain dari indeks harga saham gabungan, maka analisis serupa juga berlaku untuk return. Hasil korelasi Tabel 4 menunjukan bahwa secara sederhana hubungan RJCI dengan kebijakan moneter baik yang diantisipasi maupun surprise tidak selalu negatif. 
Tabel 4 Korelasi Perubahan Kebijakan Moneter dengan Return JCI

\begin{tabular}{lccc}
\hline \multicolumn{1}{c}{ Policy Rate } & RJCI & 3 Months Interbank Offered Rate & RJCI \\
\hline PRFED & 0,050701 & JIBORRP3MO & 0,029367 \\
PRECB & 0,028277 & KLIBOR3MO & 0,018767 \\
PRBOT & 0,02043 & BKIBOR3MO & 0,014308 \\
PRBI & 0,015468 & EURIBOR3MO & 0,011047 \\
PRBNM & $-0,012645$ & SIBOR3MO & $-0,005960$ \\
PRBOE & $-0,024940$ & LIBORGBP3MO & $-0,013366$ \\
PRMAS & $-0,034920$ & EFFR & $-0,015997$ \\
\hline
\end{tabular}

\section{Respon Return Pasar Modal Indonesia terhadap Kebijakan Moneter Domestik dan Asing}

Tabel 5 memberikan rangkuman hasil estimasi pada mean equation. Nilai yang tidak ditulis miring, tidak tebal, dan sejajar dengan keterangan variabel independennya merupakan koefisien hasil estimasi. Nilai dibawah setiap koefisien hasil estimasi adalah [standar error] koefisien. Koefisien baku didapatkan dari nilai absolut perbandingan antara koefisien hasil estimasi dengan [standar errornya] menunjukkan bahwa pengaruh yang diberikan suatu variabel independen paling besar terhadap variabel dependen yang diuji. Tanda positif atau negatif adalah kondisi bagaimana RJCI dapat dipengaruhi oleh suatu variabel independen. Implikasi dari hasil ini adalah investor portofolio internasional tidak dapat menerapkan strategi diversifikasi investasi pada keempat pasar modal ini karena mereka saling berhubungan positif.

Berdasarkan hasil estimasi, model terbaik yang didapat adalah EGARCH $(1,0)$. Hubungan RJCI dengan ketiga return pasar modal ASEAN lainnya terbukti berhubungan positif. Ini selaras dengan hasil dari analisis korelasi dan penelitian Febrian dan Herwany (2009). Febrian dan Herwany (2009) menyatakan bahwa antara JCI, KLCI, dan STI saling terkointegrasi.

Tabel 5 Koefisien, Standar Error, dan Koefisien Mean Equation

\begin{tabular}{lcc}
\hline & RJCI & Koefisien Baku \\
\hline RSTI & $0,26959^{* * * *}$ & $\mathbf{1 4 , 4 1 2 5}$ \\
RKLCI & {$[0,01871]$} & \\
& $0,46898^{* * *}$ & $\mathbf{1 5 , 0 6 6 5}$ \\
RSET & {$[0,03113]$} & \\
& $0,23806^{* * *}$ & $\mathbf{8 , 3 1 5 8 9}$ \\
RDJIA & {$[0,02863]$} & \\
\multirow{2}{*}{ PRFED } & $0,16737^{* * * *}$ & $\mathbf{5 , 1 8 4 0 1}$ \\
& {$[0,03229]$} & \\
PRBOE & $0,01439^{* * *}$ & $\mathbf{2 0 , 4 7 5 1}$ \\
\hline
\end{tabular}




\begin{tabular}{lcc}
\hline PRMAS & {$[0,00286]$} & $\mathbf{9 , 7 1 5 6 5}$ \\
& $0,00304 * * *$ \\
{$[0,00031]$} & Koefisien Baku \\
\hline PRBOT & RJCI & $\mathbf{1 , 9 0 4 2 4}$ \\
EFFR & $0,02187^{*}$ & $\mathbf{1 , 6 4 1 6 6}$ \\
LIBORGBP 3MO & {$[0,01149]$} & $\mathbf{4 , 2 7 3 9 9}$ \\
& $-0,0107^{*}$ & \\
\hline
\end{tabular}

Keterangan : $(* * *)$ signifikan pada taraf nyata $1 \%,(* *)$ siginifikan pada taraf nyata $5 \%$, (*) signifikan pada taraf nyata $10 \%$.

Pasar modal Malaysia adalah yang paling berpengaruh diantara pasar modal ASEAN lainnya terhadap pasar modal Indonesia. Ini dapat dilihat dari koefisien baku RKLCI terhadap RJCI yang merupakan nilai terbesar. Hasil ini pun sesuai dengan nilai korelasi terbesar antara RJCI dengan RKLCI dibandingan negara ASEAN lainnya. Oleh karena itu, dapat dikatakan bahwa pasar modal Indonesia paling terintegrasi dengan pasar modal Malaysia. Selain itu pasar modal Indonesia hanya terintegrasi dengan pasar modal Amerika Serikat. Ini ditunjukan dengan koefisien signifikan positif dari RDJIA terhadap RJCI.

Perubahan suku bunga acuan Bank Indonesia maupun JIBOR3MO tidak berpengaruh signifikan terhadap RJCI. Ini berarti kebijakan moneter domestik tidak berpengaruh pada pergerakan maupun performa pasar modal di Indonesia. Ini sesuai dengan penelitian Wuryandani (2011) yang menyatakan bahwa kebijakan moneter Bank Indonesia tidak terlalu berpengaruh terhadap pergerakan JCI. Hasil ini mengindikasikan bahwa jalur transmisi kebijakan moneter melalui pasar modal masih lemah.
Asumsi bahwa otoritas moneter memiliki otoritas terbatas dalam mengintervensi negara lain, maka kebijakan yang disarankan adalah menjaga stabilitas nilai tukar untuk aliran modal yang spekulatif. Hal penting lain adalah kebijakan diharapkan mengarah fokus pada perbaikan efektivitas dan efisiensi pada pasar keuangan sebagai financial intermediary.

Perubahan suku bunga acuan asing sebagai kebijakan yang ternyata mayoritas tidak berdampak negatif terhadap RJCI. Hanya suku bunga acuan dari Bank of England (Inggris) yang memberi dampak negatif terhadap RJCI (sesuai penelitian dan teori acuan), sedangkan suku bunga acuan kebijakan dari Amerika Serikat, Singapura, dan Thailand memberikan dampak positif. Sehingga perlu perhatian khusus untuk pengumuman perubahan target suku bunga dari Inggris. Walaupun suku bunga acuan Amerika Serikat yang paling berpengaruh terhadap pasar modal Indonesia jika dilihat dari hasil koefisien bakunya.

Perubahan 3 months interbank offered rate sebagai kebijakan yang surprise atau tidak diantisipasi tidak terlalu berpengaruh pada pasar modal 
Indonesia kecuali dari dua negara leading economy Amerika Serikat (EFFR) dan Inggris (LIBORGBP3MO). Walaupun hanya EFFR yang hasilnya sesuai dengan hipotesis awal yaitu berdampak negatif signifikan sesuai Bernanke dan Kuttner (2005) yang mengatakan bahwa surprise news dari perubahan suku bunga yang tidak diantisipasi akan berdampak negatif pada return saham. Ini sesuai juga dengan penelitian Kim dan Nguyen (2009) dan Abou-Zaid (2013). Sedangkan LIBORGBP3MO sebaliknya berdampak signifikan positif.

Beberapa hasil yang anomali (tidak sesuai hipotesis dan teori awal) ini merupakan dampak dari signifikannya unsur asimetris pada model EGARCH $(1,0)$ ini. Hal itu ditunjukan oleh koefisien $\gamma_{i}$ yang bernilai negatif signifikan menandakan bahwa guncangan berita negatif pada pasar modal menimbulkan volatilitas yang lebih besar daripada berita positif. Adanya asimetris informasi ini menjelaskan ketidaksesuaian reaksi return JCI terhadap beberapa variabel independen yang diuji, walaupun pasar modal negara yang diuji terintegrasi dengan pasar modal Indonesia. Ini sesuai dengan penelitian Zare et al (2013) dan Bakara dan Hermanto (2009). Bakara dan Hermanto (2009) yang menjelaskan bahwa beberapa negara ASEAN Singapura, Indonesia, dan Philipina pasar modalnya tidak efisien atau menolak model Efficient Market Hyphothesis (EMH) karena informasi bersifat asimetrik dan harga pasar tidak mencerminkan seluruh informasi publik.

\section{SIMPULAN DAN SARAN}

\section{Simpulan}

Berdasarkan hasil analisis deskriptif maupun hasil estimasi pemodelan, terbukti bahwa pasar modal Indonesia dan tiga pasar modal ASEAN lainnya saling terintegrasi. Pasar modal Indonesia dinyatakan tidak efisien karena memiliki unsur asimetrik informasi. Kebijakan moneter yang berpengaruh untuk pasar modal Indonesia hanya kebijakan asing yang bersumber dari bank sentral Amerika Serikat, Inggris, Singapura, dan Thailand.

\section{Saran}

Adapun saran yang dapat diberikan yaitu, Pemerintah, otoritas pasar modal maupun moneter, dan investor Indonesia sebaiknya memperhatikan betul mengenai kebijakan moneter yang bersumber dari bank sentral asing terutama yang menjadi leading economy di dunia seperti Amerika Serikat dan Inggris.

\section{DAFTAR PUSTAKA}

Abou-Zaid AS. 2013. International Stock Markets Response to The Federal Reserve Policy Actions: The Case of Emerging MENA Markets. International Journal of Financial Markets and Derivatives 3(2): 179-190.

Ali H. 2014. Impact of Interest Rate on Stock Market; Evidence from Pakistani Market. Journal of Business and Management 16(1): 64-6.

Awartani BMA, Corradi V. 2005. Predicting the volatility of the S\&P-500 stock index via GARCH Models: The role of 
asymmetries. International Journal of Forecasting. 21: 167-183.

Bakara MYV, Bambang H. 2009. Are South East Asia Countries Capital Markets Characterized by Nonlinear Structures? An Investigation from Indonesia, Philippine and Singapore Capital Market Indices. Indonesian Capital Market Review 1(1): 43-65.

Belke A, Joscha B. 2014. Monetary Policy and Stock Prices Cross-Country Evidence from Cointegrated VAR Models. Journal of Banking \& Finance 54(1): 254-265.

Bernanke B, Kenneth NK. 2003. What explains the stock market's reaction to Federal Reserve policy?. Proceedings, Federal Reserve Bank of San Francisco, issue Mar.

Bernanke B, Kenneth K. 2005. What Explains the Stock Market's Reaction to Federal Reserve Policy?. Journal of Finance 60(1): 1221-1257.

Dornbusch R, Stanley F, Richard S. 2008. Macroeconomics $10^{\text {th }}$ Edition. New York (US): McGraw-Hill Companies.

Dufour JM, D Tessier. 2006. ShortRun and Long-Run Causality between Monetary Policy Variables and Stock Prices. Bank of Canada Working paper.

Fama EF. 1969. Efficient Capital Markets: A Review of Theory and Empirical Work. The Journal of Finance 25(2): 383417.

Febrian E, Aldrin H. 2009. Volatility Forecasting Models And Market Co-Integration: A Study On South-East Asian Markets.
Indonesian Capital Market Review 1(1): 27-42.

Firdaus M. 2011. Aplikasi Ekonometrika: Untuk Data Panel dan Time Series. Bogor (ID): IPB Press.

Fischbacher U, T Hen, S Zeisberger. (2013). The Impact of Monetary Policy on Stock Market Bubbles and Trading Behavior: Evidence From The Lab. Journal of Economic Dynamics and Control 37(10): 2104-2122.

Gali J, L Gambetti. 2013. The Effects of Monetary Policy on Stock Market Bubbles Some Evidence. Nber Working Paper Series.

Global Business Guide Indonesia. 2017. Indonesia's Capital Market: Growing Beyond Expectations [internet]. [diacu 2018 April 11]. Tersedia dari: http://www.gbgindonesia.com/ en/finance/article/2017/indones ia_s_capital_market_growing beyond_expectations_11764.p hp

Gokbulut RI, Pekkaya M. 2014. Estimating and Forecasting Volatility of Financial Markets Using Asymmetris GARCH Models: An Application on Turkish 42 Financial Markets. International Journal of Economics and Finance. 6(4): 23-35.

Karim BA, M Shabri A, Samsul Arifin AK. 2009. Integration of Stock Markets Between Indonesia and Its Major Trading Partners. Gadjah Mada International Journal of Business 11(2): 229-252.

Kim Suk-Joong, Do Quoc Tho Nguyen. 2009. The Spillover Effect of Target Interest Rate 
News From The U.S Fed and The European Central Bank on The Asia-Pacific Stock Markets. Journal of International Financial Markets, Institution \& Money 19(1): 415-431.

Krieger K, Nathan M, Joseph V. 2015. Comparing U.S. and European Market Volatility Responses to Interest Rate Policy Announcements. International Review of Financial Analysis 39(1): 127-136.

Marfatia HA. 2014. Impact of Uncertainty on High Frequency Response of The U.S. Stock Markets to The Fed's Policy Surprises. The Quarterly Review of Economics and Finance 54(8): 382-392.

Mishkin FS. 1996. The Channels of Monetary Transmission: Lessons for Monetary Policy. Banque de France Bull. Dig 27(1): 33-44.

Mishkin FS. 2008. The Economics of Money, Banking, and Financial Market. New Jersey (US): Pearson Education.

Nguyen TTTLD, Van Duy Nguyen. 2016. Impacts of Monetary Policy and Information Shock on Stock Market: Case Study in Vietnam. International Journal of Economics and Finance 8(7): 132-139.

Oxford Business Review. 2018. Room for Growth on Indonesia's Stock Exchange [internet]. [diacu 2018 April 11]. Tersedia dari: https://oxfordbusinessgroup.co $\mathrm{m} /$ overview/all-here-large-andactive-bourse-still-has-roomgrow

Pennings S, Arief R, Hsiao CT. 2015. The Impact of Monetary Policy in Financial Markets in Small
Open Economies: More or Less Effective During The Global Financial Crisis?. Journal of Macroeconomics 44(6): 60-70.

Putri NA, Lukytawati A, Syamsul HP. 2017. Analysis of Federal Fund Rate and BI Rate Announcement to Abnormal Return In Indonesia Stock Market. International Journal of Business and Management Review 5(9): 65-77.

Ravn SH. 2014. Asymmetric Monetary Policy Towards The Stock Market: A DSGE Approach. Journal of Macroeconomics 39(1): 24-41.

Ricci O. 2015. The Impact of Monetary Policy Announcements on The Stock Price of Large European Banks During The Financial Crisis. Journal of Banking \& Finance 52(3): 245-255.

Ruiz J. 2015. Response of Spanish Stock Market to ECB Monetary Policy During Financial Crisis. Spanish Review of Financial Economics 13(2): 41-47.

Salvatore D. 1996. International Economics, Fifth Edition. New Jersey(US): Prentice Hall.

Tillmann P. 2016. Unconventional Monetary Policy and The Spillovers to Emerging Markets. Journal of International Money and Finance 66(9): 136-156.

Tamisari MD, Rina O, Dedi BD. 2016. Stock Market Integration of Asean+6 on Indonesia Composite Stock Price Index (Jkse). International Journal of Business and Management Invention 5(2): 1-7.

Tsai, CL. 2014. The Effects of Monetary Policy on Stock Returns: Financing Constraints and "Informative" and 
"Uninformative" FOMC

Statements. International

Review of Economics and

Finance 29(1): 273-290.

Vithessonthi C, Yaowaluk T. 2012.

The Impact of Monetary Policy

Decisions on Stock Returns:

Evidence from Thailand.

Journal of International

Financial Markets, Institutions

\& Money 22(1): 487-507.

Vithessonthi C, Yaowaluk T. 2013.

Do Monetary Policy

Announcements Affect Stock

Prices in Emerging Market

Countries? The case of

Thailand. Journal of

Multinational Financial

Management 23(1): 446-469.

Wang S, David GM. 2012. Monetary

Policy Announcements and

Stock Reactions: An

International Comparison.

North American Journal of Economics and Finance 23(1): 145-164.

Wuryandani G. 2011. The Behavior and Determinants of Stock Market Index in

Indonesia. Indonesian Capital Market Review 3(2): 101-116.

Yang L, Shigeyuki H. 2014. Spillover effect of US Monetary Policy to ASEAN Stock Markets: Evidence from Indonesia, Singapore, and Thailand. Pacific Basin Finance Journal 26(1):145-155.

Zare R, M Azali, MS Habibullah. 2013. Monetary Policy and Stock Market Volatility in the ASEAN5: Asymmetries over Bull and Bear Markets. Procedia Economics and Finance 7(1):18-27. 